\section{Sweetpotato Transplant Holding Duration Effects on Plant Survival and Yield}

\author{
William B. Thompson ${ }^{1}$, Jonathan R. Schultheis ${ }^{1,5}$, \\ Sushila Chaudhari ${ }^{2,4}$, David W. Monks ${ }^{1}$, Katherine M. Jennings ${ }^{1}$, \\ and Garry L. Grabow ${ }^{3}$
}

ADDITIONAL INDEX WORDS. Ipomoea batatas, plant stand, storage root number

SumMary. Studies were conducted in North Carolina to determine the effect of holding durations (HDs) $[0,1,3,5$, and 7 days before planting (DBP)] of 'Covington' sweetpotato (Ipomoea batatas) transplants on plant stand and storage root numbers and yield in production fields. In a second field study, the effect of preplant irrigation (PI) treatments (PI and nonirrigation) were evaluated along with the transplant HD on plant stand, storage root numbers, and yield. Transplants held for 7 DBP did not survive as well as the other treatments (lower plant stands) and had lower no. 1, marketable, and total storage root numbers and yields than other holding treatments. HD of 1 or 3 DBP resulted in higher plant stands, and no. 1, marketable, and total numbers of storage roots and yields than holding for 0,5 , or 7 DBP. This study affirms the importance of soil moisture at and shortly after planting for transplant survival and yield. Holding transplants for 1-3 DBP can improve stand establishment and yields when dry conditions occur either before or soon after planting. However, holding transplants for $7 \mathrm{DBP}$ can result in reduced plant stands and yields when stress/dry conditions occur soon after planting.

$\mathrm{N}$ orth Carolina ranks number one in sweetpotato production in the United States with 87,000 acres planted $(\$ 332$ million in gross farm value) in 2015 and accounts for more than half of the total acreage planted nationwide (U.S. Department of Agriculture, 2016). 'Covington' sweetpotato is the most commonly grown cultivar in North

$\overline{\text { We acknowledge and thank Jonathan Monks, summer }}$ interns, graduate students, and all the staff at Jones Farm, Bailey; Horticulture Crops Research Station, Clinton; and Cunningham Research Station, Kinston, for their assistance in planting and managing the research plots. In addition, we thank Joy Smith for her assistance with the statistical analysis of the collected data. Finally, we would like to acknowledge the U.S. Department of Agriculture which administers the Specialty Crop Research Initiative Grant Program, and the North Carolina Sweetpotato Commission, Inc. for their financial support of this project.

Mention of a trademark, proprietary product, or vendor does not constitute a guarantee or warranty of the product by the North Carolina State University and does not imply its approval to the exclusion of other products or vendors that also may be suitable.

${ }^{1}$ Department of Horticultural Science, North Carolina State University, Campus Box 7609, 2721 Founders Drive, Raleigh, NC 27695

${ }^{2}$ Department of Crop and Soil Sciences, North Carolina State University, Campus Box 7620, Raleigh, NC 27695

${ }^{3}$ Department of Biological and Agricultural Engineering, North Carolina State University, Campus Box 7625, Raleigh, NC 27695

${ }^{4}$ Postdoctoral Research Scholar

${ }^{5}$ Corresponding author. E-mail: jonathan_schultheis@ ncsu.edu.

doi: 10.21273/HORTTECH03808-17
Carolina (North Carolina Crop Improvement Association, 2014). The wide adoption of 'Covington' is because of its disease resistance and consistency to produce a high percentage of no. 1 grade sweetpotato roots that result in excellent economic return. For improved storage root yield and quality, growers must closely follow recommended growing practices in the production field (Kemble, 2013). However, production practices in the propagation bed and transplant (nonrooted stem cuttings, which are also referred to as slips) cutting practices are often overlooked both in research and in practice within production fields. The practice of holding transplants for a few DBP is thought by many North Carolina growers to allow for transplants to produce adventitious roots before planting in the production field
(J. Jones, personal communication). These growers believe that transplants that have been held to initiate adventitious roots before planting in the field will establish more successfully than transplants cut from propagation beds and planted on the same day. The beneficial effects of holding transplants before planting were reported to increase storage root yields in sweetpotato (Beyene et al., 2015; Hammett, 1983; Nwinyi, 1991; Ravindran and Mohankumar, 1989). However, there is limited information with respect to the optimum HD of 'Covington' transplants before planting under North Carolina sweetpotato growing conditions.

Storage roots are the principal carbohydrate storage organ in sweetpotato, and each root is a length of adventitious root that forms a localized carbohydrate storage structure. They are defined by their distinctive lateral growth (Lewthwaite and Triggs, 2009). The role of adventitious root formation is critical to storage root formation. Villordon et al. (2009) reported that adventitious roots started within $7 \mathrm{~d}$ after planting (DAP) comprised $86 \%$ of final storage root yield of 'Beauregard' sweetpotato under certain conditions. The initial adventitious roots originate from preformed root primordia that are commonly visible on the aerial stem at the time of cutting (Belehu et al., 2004; Hahn and Hozyo, 1983). These root primordia typically form in pairs on either side of the stem just below the nodes or leaves (Togari, 1950). Adventitious rooting can also develop within the callus tissue that forms on the buried end of a transplanted sweetpotato stem cutting. However, early storage roots develop from the initial adventitious roots preformed at nodes before planting rather than from those initiated later in the stem end callus (Lewthwaite and Triggs, 2009). Any

\begin{tabular}{llll}
\hline $\begin{array}{l}\text { Units } \\
\text { To convert U.S. to SI, } \\
\text { multiply by }\end{array}$ & U.S. unit & SI unit & $\begin{array}{l}\text { To convert SI to U.S., } \\
\text { multiply by }\end{array}$ \\
\hline 0.4047 & acre(s) & $\mathrm{ha}$ & 2.4711 \\
102.7902 & acre-inch $(\mathrm{es})$ & $\mathrm{m}^{3}$ & 0.0097 \\
0.3048 & $\mathrm{ft}$ & $\mathrm{m}$ & 3.2808 \\
2.54 & inch(es) & $\mathrm{cm}$ & 0.3937 \\
25.4 & inch(es) & $\mathrm{mm}$ & 0.0394 \\
0.4536 & lb & $\mathrm{kg}$ & 2.2046 \\
1.1209 & lb/acre & $\mathrm{kg} \cdot \mathrm{ha}^{-1}$ & 0.8922 \\
$\left({ }^{\circ} \mathrm{F}-32\right) \div 1.8$ & ${ }^{\circ} \mathrm{F}$ & ${ }^{\circ} \mathrm{C}$ & $\left({ }^{\circ} \mathrm{C} \times 1.8\right)+32$ \\
& & & \\
\hline
\end{tabular}


event that limits carbohydrate deposition, or the cambial activity associated with the development of a fully formed storage root will temporarily or permanently obstruct the progress of a storage root during the season (Kays, 1985; Meyers et al., 2017; Togari, 1950). Togari (1950) reported that management and environmental variables within the first 20 DAP influenced adventitious root cambium activity in sweetpotato and the rate of storage root initiation, which in turn determined yield. These conditions include water-logged soils that expose roots to prolonged periods of oxygen deficiency or long periods of drought that can lead to the formation of pencil roots. Pencil roots have limited carbohydrate storage function as the stele may be partially lignified, which allows for some lateral thickening to occur (Wilson, 1970).

Environmental conditions such as precipitation and initial soil moisture have been shown to be the key components for transplant survival and storage root set in sweetpotato (Gajanayake et al., 2013; Thompson et al., 2017). Soil moisture stress is detrimental during plant establishment and can limit the initial growth and development of sweetpotato roots that eventually affect storage root yield (Gajanayake et al., 2013; Pardales and Yamauchi, 2003; Pardales et al., 2000). Villordon et al. (2012) reported that available soil moisture at the time of planting through 20 DAP was critical in influencing whether adventitious roots became storage or pencil roots. Sweetpotato is considered a relatively droughttolerant crop (Pardales et al., 2000) and average yields have been reported in production systems suffering drought stress (Bouwkamp, 1985). Previous studies have demonstrated average yields in drought conditions; however, yield benefits from supplemental irrigation have been demonstrated when rainfall is not adequate or where moisture distribution is erratic and unpredictable (Bouwkamp, 1985). Rainfall can be sporadic in North Carolina after sweetpotato planting or during the growing season. The use of additional irrigation after planting and through the growing season is not usually practiced by growers in North Carolina. However, in California, $100 \%$ of the sweetpotato crop is irrigated through the use of drip or furrow irrigation because of very little rainfall during the growing season (Stoddard et al., 2013). The use of irrigation would not only maximize plant stand and storage root yield, but also allow transplants that have been held for long periods of time to have the ability to survive and produce good quality sweetpotato storage roots.

A significant number of transplants are shipped out of state and comprise an important portion of the North Carolina sweetpotato transplant production business (J. Jones, G. Warren, and R. Glover, personal communication). The authors are unaware of any literature that addresses the effect of shipping duration, which increases transplant holding time, on sweetpotato transplant survival. In general, sellers suggest planting of transplants as soon as they arrive or storing transplants for not more than $10 \mathrm{~d}$ (if planting conditions are not suitable) to avoid any negative effect on sweetpotato root quality and yield (Sand Hill Preservation Center, 2017). Therefore, it is important to determine how longer durations of transplant holding affect plant stands and yields.

Thus, the objective of this research was to determine the effect of 'Covington' sweetpotato transplant HD before planting on plant survivability, and storage root yield and quality. The effect of transplant HD on plant survivability, storage root yield, and quality was also investigated with and without PI at the time of sweetpotato transplant planting.

\section{Materials and methods}

Field studies were conducted at the Jones Farm, Bailey, NC (lat. $35.8247^{\circ} \mathrm{N}$, long. $\left.78.1250^{\circ} \mathrm{W}\right)$; Cunningham Research Station (CRS), Kinston, NC (lat. $35.2917^{\circ} \mathrm{N}$, long. $77.5590^{\circ} \mathrm{W}$ ); and Horticulture Crops Research Station (HCRS), Clinton, NC (lat. $34.9979^{\circ} \mathrm{N}$, long. $\left.78.3233^{\circ} \mathrm{W}\right)$. Soil was a Norfolk (fine-loamy, kaolinitic, thermic Typic Kandiudults) at Jones Farm, Norfolk or Goldsboro (fine-loamy, siliceous, subactive, thermic Aquic Paleudults) at CRS, and Norfolk or Orangeburg (fine-loamy, kaolinitic, thermic Typic Kandiudults) at HCRS. Soils at these locations are representative of the southeastern U.S. sweetpotato production region. All studies were culturally managed in accordance with North Carolina recommendations for fertilization, weed, insect, and disease management (Kemble, 2013).

\section{Study 1}

Studies were conducted at Bailey and Kinston in 2010 and 2011, and at Clinton in 2011. Treatments included holding transplants for $0,1,3,5$, and 7 DBP. Fields were not irrigated before or after transplants were planted. Treatments were arranged in a randomized complete block design with four replications.

\section{Study 2}

Studies were conducted at Clinton in 2012 and 2013. A complete set of HD of transplant treatments $(0,1$, 3,5 , and 7 DBP) was arranged in a randomized complete block design with four replications in nonirrigated and preplant irrigated plots. To ensure optimal soil moisture levels, irrigation of 0.5 acre-inch was applied to the preplant irrigated portion of the field $1 \mathrm{DBP}$ and $1 \mathrm{DAP}$ using a linear move system. Irrigated plots were placed on opposite sides within the same field with a border area of 10 rows between the plantings to ensure no water overspray between PI treatments.

For all the studies, generation two transplants (Milholland and Averre, 2008) were obtained from either Jones Farm (2010 and 2011) or Scott Farm, Lucama, NC (2012 and 2013). After cutting, transplants were held within a storage shed at Jones Farm in 2010 and at North Carolina State University, Raleigh, in 2011, 2012, and 2013 for the duration of the specified treatment. Transplants were stored at 75 to $84^{\circ} \mathrm{F}$ and $60 \%$ to $70 \%$ relative humidity. Transplants were planted and simultaneously watered using a mechanical transplanter, which is the standard commercial practice for sweetpotato plant establishment (Kemble, 2013). Planting dates varied among study locations and years and are reported in Table 1. Each plot consisted of four rows on a 12-inch-tall bed, with each 30-ft-long row on 3.5-ft centers. The exceptions were at Kinston 2010 where the rows were 25-ft long and at Bailey with a between-row spacing of $3.6 \mathrm{ft}$. Transplants were spaced $\approx 1$ $\mathrm{ft}$ apart in row. Thirty transplants were planted per row except at Kinston 2010 as only 25 transplants were planted per row because of the shorter 
Table 1. Sweetpotato planting and harvest [days after planting (DAP)] information for studies conducted from 2011 to 2013 at Baily, Clinton, and Kinston, NC.

\begin{tabular}{|c|c|c|c|c|c|c|c|c|c|c|c|c|}
\hline \multicolumn{7}{|c|}{ Study 1} & \multicolumn{6}{|c|}{ Study 2} \\
\hline \multirow[b]{2}{*}{ Location } & \multicolumn{3}{|c|}{2010} & \multicolumn{3}{|c|}{2011} & \multicolumn{3}{|c|}{2012} & \multicolumn{3}{|c|}{2013} \\
\hline & Plant & Harvest & $\overline{\mathrm{DAP}}$ & Plant & Harvest & $\overline{\mathrm{DAP}}$ & Plant & Harvest & $\overline{\mathrm{DAP}}$ & Plant & Harvest & DAP \\
\hline Kinston & 25 June & 3 Nov. & 132 & 21 June & 10 Oct. & 111 & - & - & - & - & - & - \\
\hline Clinton & - & - & - & 23 June & 25 Oct. & 124 & 19 June & 9 Oct. & 113 & 20 June & 9 Oct. & 111 \\
\hline
\end{tabular}

row length at that location. Rainfall data were collected from either onsite weather stations or from regional weather stations, and provided by the State Climate Office in North Carolina.

Once plants had been established, plant stands were recorded at 2-3 weeks after planting. The center two rows of each plot were harvested with a tractor-mounted chain digger 111-132 DAP (Table 1). Storage roots were graded into no. 1 (diameter of 1.75-3.5 inches and length of 3-9 inches), canner (diameter 1-1.75 inches), jumbo (diameter $>3.5$ inches), and cull (malformed, distorted, or diseased) and then counted and weighed (U.S. Department of Agriculture, 2005). Marketable number and yield were calculated as the sum of no. 1 , jumbo, and canner grades.

Statistical analysis. Data from both studies were analyzed separately. All data were checked for homogeneity of variance and normality. All the data were subjected to analysis of variance using the PROC GLIMMIX procedure of SAS (version 9.4; SAS Institute, Cary, NC) to test for treatment effects and interactions. Means were separated using Tukey's honest significant difference test at the 0.05 significance level when appropriate. Environments were classified as specific combinations of year, location, or both. In Study 1, environment, transplants $\mathrm{HD}$, and their interaction were considered fixed effects, whereas replication within environment was considered a random effect. In Study 2, environment, transplants HD, PI treatments, and their interaction were considered fixed effects, whereas replication within environment was considered a random effect.

\section{Results and discussion}

STudy 1. Percent plant stand was influenced by the interaction of environment and transplants HD $(P<0.001)$;

Table 2. Percent plant stand of sweetpotato in response to transplant holding duration (HD) at Baily, Clinton, and Kinston, NC, in 2010 and 2011 (Study 1).

\begin{tabular}{|c|c|c|c|c|c|}
\hline \multirow[b]{3}{*}{$\mathrm{HD}(\mathrm{d})$} & \multicolumn{2}{|c|}{ Bailey } & \multicolumn{2}{|c|}{ Kinston } & \multirow{2}{*}{$\frac{\text { Clinton }}{2011}$} \\
\hline & 2010 & 2011 & 2010 & 2011 & \\
\hline & \multicolumn{5}{|c|}{ Plant stand $(\%)^{\mathrm{z}}$} \\
\hline 0 & $82 \mathrm{a}^{\mathrm{y}}$ & $71 \mathrm{bc}$ & $88 \mathrm{a}$ & $100 \mathrm{a}$ & $98 \mathrm{a}$ \\
\hline 1 & $86 a$ & $83 \mathrm{a}$ & $91 \mathrm{a}$ & $97 \mathrm{a}$ & $100 \mathrm{a}$ \\
\hline 3 & $93 a$ & $87 \mathrm{a}$ & $92 \mathrm{a}$ & $98 \mathrm{a}$ & $98 a$ \\
\hline 5 & $95 \mathrm{a}$ & $67 c$ & $92 \mathrm{a}$ & $98 \mathrm{a}$ & $97 \mathrm{a}$ \\
\hline 7 & $55 \mathrm{~b}$ & $54 \mathrm{~d}$ & $84 \mathrm{a}$ & $96 a$ & $99 \mathrm{a}$ \\
\hline
\end{tabular}

${ }^{\mathrm{z}}$ Percent plant stand $=($ number of plant stands per plot $/$ maximum plant stand $) \times 100 ;$ maximum plant stand value was 60 plants except for Kinston 2010-it was 50 plants.

${ }^{\mathrm{y}}$ Means followed by a different letter within a column are significantly different according to Tukey's honestly significant difference $(\alpha=0.05)$.

therefore, data were presented by each environment (Table 2). This interaction occurred because percent plant stand for Kinston (2010 and 2011) and Clinton (2011) was similar for all transplants' HD, whereas at Bailey (2010 and 2011), the effect of HD was significant. At Bailey in 2010, percent plant stands were lower when transplants were held for 7 DBP (55\%) compared with all other HDs. However, at Bailey in 2011, transplant HDs of 0,5 , or 7 DBP had lower percent plant stand than 1 or $3 \mathrm{DBP}$ HDs.

Interactions between environment and transplant HD were not observed for any of the storage root numbers and yields except for no. 1 root numbers; therefore, data are presented by main effects (Table 3 ). The effect of environment was significant for root numbers and yield in all grades, with the exception being jumbo number. Significantly lower root numbers and yields were reported from Bailey 2010 and 2011 than from all other environments. Rainfall data showed that the Bailey location had consistently lower amounts of rainfall within the first 15 DAP than the other locations in 2010 and 2011 (Fig. 1), which likely created moisture stress resulting in the lowest yields.

The main effect of transplant HD was significant for no. 1, canner, marketable, and total root yields ( $\mathrm{Ta}$ ble 3 ). Transplants held for 1 or 3 DBP had greater no. 1, marketable, and total root yields than transplants held for 7 DBP. The effect of HD was not significant for jumbo root yield and numbers and canner root numbers. Lower no. 1 root number was obtained from the $7 \mathrm{DBP}$ treatment compared with all other HDs. Marketable and total root numbers were reported highest when transplants were held for 3 DBP and lowest when transplants were held for either 0 or $7 \mathrm{DBP}$.

STUDY 2. The interaction for environment by HD by PI was significant for percent plant stand; therefore, data were presented separately for 2012 and 2013. The interaction occurred because the main effects of HD and PI were significant in 2012, whereas they were not significant in 2013 (Table 4). In 2012, percent plant stand for 7 DBP was lower than that of all other HDs. In 2012, percent plant stand was lower when transplants were planted under preplant irrigated plots (90\%) as compared with nonirrigated plots (97\%).

The interaction for environment by HD by PI was not significant for numbers $(P=0.079-0.399)$ and yields $(P=0.174-0.798)$ of no. 1 , jumbo, canner, marketable, and total roots; therefore, data were combined over both the years. The interaction 
Table 3. Sweetpotato storage roots yield and number in response to transplant holding duration (HD) and environment at Baily, Clinton, and Kinston, NC, in 2010 and 2011 (Study 1).

\begin{tabular}{|c|c|c|c|c|c|c|c|c|c|c|}
\hline \multirow[b]{2}{*}{ Main effect } & No. 1 & Jumbo & Canner & Marketable $^{\mathrm{z}}$ & Total & No. 1 & Jumbo & Canner & Marketable & Total \\
\hline & \multicolumn{5}{|c|}{ Yield (bushels/acre) $^{\mathrm{y}}$} & \multicolumn{5}{|c|}{ Roots $(1,000 / \text { acre })^{y}$} \\
\hline \multicolumn{11}{|l|}{ Environments (E) } \\
\hline Kinston, 2010 & $505 \mathrm{cb}^{\mathrm{x}}$ & $252 \mathrm{a}$ & $67 \mathrm{a}$ & $887 \mathrm{~b}$ & $935 \mathrm{a}$ & $37 \mathrm{~b}$ & $6 a$ & $25 \mathrm{a}$ & $69 \mathrm{~b}$ & $72 \mathrm{~b}$ \\
\hline Kinston, 2011 & $615 b$ & $202 \mathrm{a}$ & $58 \mathrm{a}$ & $933 \mathrm{ab}$ & $946 \mathrm{a}$ & $54 \mathrm{a}$ & $6 a$ & $22 \mathrm{a}$ & $82 \mathrm{a}$ & $83 \mathrm{a}$ \\
\hline Bailey, 2010 & $358 \mathrm{~d}$ & $53 \mathrm{~b}$ & $63 a$ & $460 \mathrm{c}$ & $479 \mathrm{~b}$ & $31 \mathrm{c}$ & $2 \mathrm{a}$ & $23 \mathrm{a}$ & $57 \mathrm{c}$ & $60 \mathrm{c}$ \\
\hline Bailey, 2011 & $426 \mathrm{~cd}$ & $84 \mathrm{~b}$ & $42 \mathrm{~b}$ & $506 \mathrm{c}$ & $543 \mathrm{~b}$ & $29 \mathrm{c}$ & $2 \mathrm{a}$ & $14 \mathrm{~b}$ & $46 \mathrm{~d}$ & $49 \mathrm{~d}$ \\
\hline Clinton, 2011 & 748 a & $230 \mathrm{a}$ & $65 \mathrm{a}$ & $994 \mathrm{a}$ & 997 a & $57 \mathrm{a}$ & $7 \mathrm{a}$ & $26 a$ & $90 \mathrm{a}$ & $90 \mathrm{a}$ \\
\hline \multicolumn{11}{|l|}{$\mathrm{HD}$} \\
\hline $0 \mathrm{~d}$ & $531 \mathrm{a}$ & $167 \mathrm{a}$ & $56 \mathrm{ab}$ & $755 \mathrm{ab}$ & $774 \mathrm{ab}$ & $41 \mathrm{a}$ & $4 \mathrm{a}$ & $21 \mathrm{a}$ & $67 \mathrm{~b}$ & $68 \mathrm{~b}$ \\
\hline $1 \mathrm{~d}$ & $564 \mathrm{a}$ & $181 \mathrm{a}$ & $53 \mathrm{~b}$ & $799 \mathrm{a}$ & 822 a & $43 a$ & $5 \mathrm{a}$ & $20 \mathrm{a}$ & $68 \mathrm{ab}$ & $70 \mathrm{ab}$ \\
\hline $3 \mathrm{~d}$ & $558 \mathrm{a}$ & $160 \mathrm{a}$ & $62 \mathrm{ab}$ & $781 \mathrm{a}$ & 801 a & $45 \mathrm{a}$ & $4 \mathrm{a}$ & $24 \mathrm{a}$ & $73 \mathrm{a}$ & $75 a$ \\
\hline $5 \mathrm{~d}$ & $523 \mathrm{ab}$ & $151 \mathrm{a}$ & $66 \mathrm{a}$ & $746 \mathrm{ab}$ & $766 \mathrm{ab}$ & $42 \mathrm{a}$ & $4 \mathrm{a}$ & $24 \mathrm{a}$ & $70 \mathrm{ab}$ & $72 \mathrm{ab}$ \\
\hline $7 \mathrm{~d}$ & $476 \mathrm{~b}$ & $162 \mathrm{a}$ & $59 \mathrm{ab}$ & $699 \mathrm{~b}$ & 737 b & $37 \mathrm{~b}$ & 5 a & $23 \mathrm{a}$ & $65 \mathrm{~b}$ & $69 \mathrm{~b}$ \\
\hline $\mathrm{E} \times \mathrm{HD}(P$ value $)$ & 0.111 & 0.291 & 0.33 & 0.269 & 0.662 & 0.008 & 0.626 & 0.127 & 0.118 & 0.106 \\
\hline
\end{tabular}

${ }^{\mathrm{z}}$ Marketable yield or number $=$ no. $1+$ canner + jumbo; total yield or number $=$ marketable + cull; no. 1 roots are 1.75 to 3.5 inch in diameter and 3 to 9 inch in length, canner roots are 1 to 1.75 inch in diameter, jumbo roots are $>3.5$ inch in diameter, and cull roots are malformed or distorted; 1 inch $=2.54 \mathrm{~cm}$.

${ }^{\mathrm{y}} 150-\mathrm{lb}(22.68 \mathrm{~kg})$ bushel $/ \mathrm{acre}=56.0426 \mathrm{~kg} \cdot \mathrm{ha}^{-1}, 1,000 \mathrm{roots} / \mathrm{acre}=2,471.0538 \mathrm{roots} / \mathrm{ha}$.

${ }^{\mathrm{x}}$ Means within columns for main effects (environment or HD) followed by a different letter are significantly different according to Tukey's honestly significant difference $(\alpha=0.05)$.

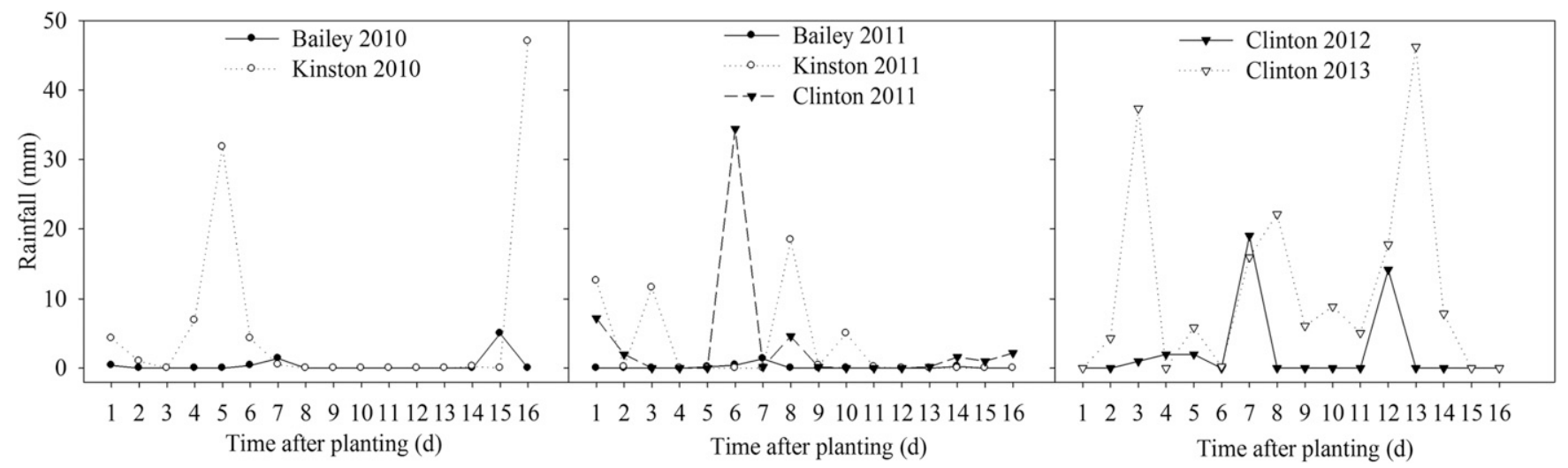

Fig. 1. Rainfall from 0 to $16 \mathrm{~d}$ after sweetpotato planting at Baily, Clinton, and Kinston, NC, from 2010 to 2013 . Rainfall data were collected from either on-site weather stations or from regional weather stations and provided by the State Climate Office in North Carolina; $1 \mathrm{~mm}=\mathbf{0 . 0 3 9 4}$ inch.

for main effects of HD by PI was not significant for numbers and yields of no. 1, jumbo, canner, marketable, and total roots; therefore, data for the main effects were combined (Table 5). No. 1, jumbo, canner, marketable, and total root yields were all statistically the same regardless of preplant irrigated or nonirrigated treatments. The effect of PI was only significant for no. 1, marketable, and total root numbers, and higher root numbers of these grades were obtained from the nonirrigated treatment compared with the preplant irrigated treatment. The yields of no. 1, marketable, and total roots were greatest for HD of 1 DBP and lowest for 5 DBP. The root numbers for all grades were similar across all HDs.
Table 4. Percent plant stand of sweetpotato in response to transplant holding duration (HD) and preplant irrigation (PI) at Clinton, NC, during 2012 and 2013 (Study 2).

\begin{tabular}{lcc}
\hline & $\mathbf{2 0 1 2}$ & $\mathbf{2 0 1 3}$ \\
\cline { 2 - 3 } Main effect & \multicolumn{1}{c}{ Plant stand (\%) $^{\mathbf{z}}$} \\
\hline PI & & \\
$\quad$ Preplant irrigated & & $96 \mathrm{a}$ \\
Nonirrigated & $90 \mathrm{~b}^{\mathrm{x}}$ & $97 \mathrm{a}$ \\
HD & $97 \mathrm{a}$ & \\
$0 \mathrm{~d}$ & & $95 \mathrm{a}$ \\
1 d & $97 \mathrm{a}$ & $97 \mathrm{a}$ \\
$3 \mathrm{~d}$ & $95 \mathrm{a}$ & $98 \mathrm{a}$ \\
$5 \mathrm{~d}$ & $93 \mathrm{a}$ & $95 \mathrm{a}$ \\
$7 \mathrm{~d}$ & $95 \mathrm{a}$ & $98 \mathrm{a}$ \\
PI $\times$ HD $(P$ value $)$ & $89 \mathrm{~b}$ & 0.086 \\
\hline
\end{tabular}

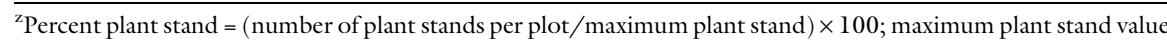
was 60 plants.

y Preplant irrigated treatment received 0.5 acre-inch $\left(51.4 \mathrm{~m}^{3}\right)$ irrigation using a linear move system.

${ }^{\mathrm{x}}$ Means within columns for main effects (HD or PI) followed by a different letter are significantly different according to Tukey's honestly significant difference $(\alpha=0.05)$. 
Table 5. Sweetpotato storage roots yield and number in response to transplant holding duration (HD) and preplant irrigation (PI) at Clinton, NC, combined for 2012 and 2013 (Study 2).

\begin{tabular}{|c|c|c|c|c|c|c|c|c|c|c|}
\hline \multirow[b]{2}{*}{ Main effect } & No. 1 & Jumbo & Canner & Marketable $^{\mathrm{z}}$ & Total & No. 1 & Jumbo & Canner & Marketable & Total \\
\hline & \multicolumn{5}{|c|}{ Yield (bushels/acre) $^{\mathrm{y}}$} & \multicolumn{5}{|c|}{ Roots $(1,000 / \text { acre })^{\mathrm{y}}$} \\
\hline \multicolumn{11}{|l|}{ PI } \\
\hline Nonirrigated & $423 \mathrm{a}$ & $91 \mathrm{a}$ & $113 \mathrm{a}$ & $639 a$ & 649 a & $40 \mathrm{a}$ & $3 a$ & $34 \mathrm{a}$ & $76 \mathrm{a}$ & $77 \mathrm{a}$ \\
\hline \multicolumn{11}{|l|}{$\mathrm{HD}$} \\
\hline $0 \mathrm{~d}$ & $435 \mathrm{ab}$ & $95 \mathrm{a}$ & $107 \mathrm{a}$ & $649 \mathrm{ab}$ & $658 \mathrm{ab}$ & 39 a & $3 \mathrm{a}$ & $30 \mathrm{a}$ & $72 \mathrm{a}$ & $73 \mathrm{a}$ \\
\hline $5 \mathrm{~d}$ & $379 \mathrm{~b}$ & $85 \mathrm{a}$ & $118 \mathrm{a}$ & $593 \mathrm{~b}$ & $603 \mathrm{~b}$ & $36 \mathrm{a}$ & $3 a$ & $36 a$ & $75 \mathrm{a}$ & $76 \mathrm{a}$ \\
\hline $7 \mathrm{~d}$ & $428 \mathrm{ab}$ & $95 \mathrm{a}$ & $109 \mathrm{a}$ & $643 \mathrm{ab}$ & $656 \mathrm{ab}$ & $39 a$ & $3 \mathrm{a}$ & $32 \mathrm{a}$ & $74 \mathrm{a}$ & $75 \mathrm{a}$ \\
\hline $\mathrm{PI} \times \mathrm{HD}(P$ value $)$ & 0.589 & 0.817 & 0.819 & 0.805 & 0.873 & 0.115 & 0.730 & 0.863 & 0.513 & 0.574 \\
\hline
\end{tabular}

${ }^{\mathrm{z}}$ Marketable yield or number $=$ no. $1+$ canner + jumbo; total yield or number $=$ marketable + cull; no. 1 roots are 1.75 to 3.5 inch in diameter and 3 to 9 inch in length; canner roots are 1 to 1.75 inch in diameter; jumbo roots are $>3.5$ inch in diameter; and cull roots are malformed or distorted; 1 inch $=2.54 \mathrm{~cm}$.

${ }^{y} 150-\mathrm{lb}(22.68 \mathrm{~kg})$ bushel $/$ acre $=56.0426 \mathrm{~kg} \cdot \mathrm{ha} \mathrm{a}^{-1}, 1,000$ roots $/$ acre $=2,471.0538 \mathrm{roots} / \mathrm{ha}$

${ }^{x}$ Preplant irrigated treatment received 0.5 acre-inch $\left(51.4 \mathrm{~m}^{3}\right)$ irrigation using a linear move system.

${ }^{w}$ Means within columns for main effects (HD or PI) followed by a different letter are significantly different according to Tukey's honestly significant difference $(\alpha=0.05)$.

The amount of precipitation is important because soil moisture markedly influences storage root initiation (Gajanayake et al., 2013). Villordon et al. (2009) have shown that storage root development begins $\approx 13 \mathrm{DAP}$, and any moisture deficit before and during this stage will detrimentally affect final storage root numbers and yields. Villordon et al. (2012) and Togari (1950) emphasized that the growing environment during the early season (first $20 \mathrm{~d}$ ) has a direct and significant impact on storage root initiation, which in turn determined the final yield. Togari (1950) also observed that dryness or compactness of soil increased cambium activity but led to increased lignification, resulting in the formation of pencil-like storage roots. Rainfall data showed that Bailey (2010 and 2011) had consistently lower amounts of rainfall within the first $15 \mathrm{DAP}$ than the other locations (Fig. 1). Limited rainfall likely created moisture stress and subsequently produced the lowest percent plant stands and yields at Bailey (2010 and 2011) compared with Clinton (2011) and Kinston (2010 and 2011).

The PI component that was implemented in 2012 and 2013 at Clinton was included as a treatment to follow up on the results that had been observed in Study l at Bailey (dry) and Kinston (more optimal soil conditions). Unfortunately, the 2012 and 2013 growing seasons were wet, especially during planting (Fig. 1). Because of this, soil moisture could be similar for the preplant irrigated and nonirrigated portions of the fields. The similar soil moisture available to the plants during the growing season resulted in no differences for percent plant stand and yield between preplant irrigated and nonirrigated conditions.

In both studies, transplant HD of 1 or 3 DBP resulted in higher percent plant stands and sweetpotato yields than 0,5 , and $7 \mathrm{~d}$. The beneficial effects of holding transplants before planting on the increase in storage root yields in sweetpotato have been observed by other researchers (Beyene et al., 2015; Hall, 1985; Hammett, 1983; Nwinyi, 1991; Ravindran and Mohankumar, 1989). Beyene et al. (2015) reported significantly higher marketable grade yield when transplants were held for 2 and $4 \mathrm{~d}$ than immediate planting and $6 \mathrm{~d}$ under shade. Similarly, Hammett (1983) reported that sweetpotato transplants held for $3 \mathrm{~d}$ under shade before planting produced highest marketable root yields followed by 4-d-old transplants relative to transplants that were obtained and planted on the same day. Transplants with intact leaves that are stored under shade for $2 \mathrm{DBP}$ promote better root initiation, easy establishment of vines, and higher root yield (Ravindran and Mohankumar, 1989). The beneficial effects of holding sweetpotato transplants had been reported to be associated with the translocation of carbohydrates toward the rooting sites without discernible loss of nutrient reserves by respiration and defoliation with a decrease in levels of indole-3acetic acid at rooting sites (Nakatani et al., 1987). Although we did not investigate the effect of hormones in our study, the role of plant hormones in adventitious rooting in sweetpotato has been investigated (Nakatani et al., 1987; Villordon et al., 2012).

The findings from this study provide a timeline for transplant HD before planting to farmers and to transplant shippers. These results show that a transplant HD of $1-3$ DBP can be beneficial, resulting in better yields and improved plant stands. However, a transplant HD of 7 DBP may have a negative influence on stand establishment and yield. This research also shows that soil moisture plays an important role for transplant survival and yield. Holding transplants for 1-3 DBP may be beneficial for stand establishment and yields when dry conditions occur either before or soon after planting. To maximize sweetpotato transplant quality when being shipped either domestically or internationally, it is important that shipment time be efficient and timely so transplant quality is not compromised. However, future research is needed to understand the impact of environmental conditions on sweetpotato transplant survival.

\section{Literature cited}

Belehu, T., P.S. Hammes, and P.J. Robbertse. 2004. The origin and structure of adventitious roots in sweetpotato (Ipomoea batatas). Austral. J. Bot. 52:551-558.

Beyene, K., A. Nebiyu, and M. Getachew. 2015. Effect of number of nodes and storage duration of vine cuttings on growth, yield and yield components of 
sweet potato (Ipomoea batatas L.) at Jimma, southwest Ethiopia. J. Biol. Agr. Healthcare 22:51-64.

Bouwkamp, J.C. 1985. Production requirements, p. 1-33. In: J.C. Bouwkamp (ed.). Sweet potato products: A natural resource for the tropics. CRC Press, Boca Raton, FL.

Gajanayake, B., K.R. Reddy, M.W. Shankle, and R.A. Arancibia. 2013. Early-season soil moisture deficit reduces sweetpotato storage root initiation and development. HortScience 48:1457-1462.

Hahn, S.K. and Y. Hozyo. 1983. Sweet potato and yam, p. 319-341. Symp. on Potential Productivity of Field Crops under Different Environments. Intl. Rice Res. Inst., Los Banos Laguna, Philippines.

Hall, M.R. 1985. Influence of storage conditions and duration on weight loss in storage, field survival and root yield of sweet potato transplants. HortScience 20:200-203.

Hammett, H.L. 1983. Effects of holding sweet potato cuttings. Lousiana Agr. Expt. Sta. Circ. 26:6-7.

Kays, S.J. 1985. The physiology of yield in the sweet potato, p. 79-132. In: J.C. Bouwkamp (ed.). Sweet potato products: A natural resource for the tropics. CRC Press, Boca Raton, FL.

Kemble, J.M. 2013. 2013 Southeastern U.S. vegetable crop handbook. Vance Publ., Lincolnshire, IL.

Lewthwaite, S.L. and C.M. Triggs. 2009. Preliminary study of the spatial distribution of sweet potato storage roots. Agron. N.Z. 39:111-122.

Meyers, S., M.W. Shankle, J. Main, B. Gajanayake, and K.R. Reddy. 2017.
Sweetpotato storage root initiation. Mississippi State Univ. Ext. Publ. 2809.

Milholland, R.D. and C.W. Averre. 2008. Sweetpotato operations manual for the production of micropropagated-certified planting stock. 2nd ed. Dept. Plant Pathol., North Carolina State Univ., Raleigh, NC.

Nakatani, M., A. Oyanagi, and Y. Watanabe. 1987. Holding of cut-sprouts in sweet potato (Ipomoea batatas Lam.) II. Physiological changes in cut-sprouts during the holding period. Jpn. J. Crop. Sci. 56:244-251.

North Carolina Crop Improvement Association. 2014. Seed list 2013-2014. 22 Apr. 2015. <http://www.nccrop.com/ varieties.php $/ 8 /$ Sweetpotato $>$.

Nwinyi, S.C.O. 1991. Pre-planting method and duration of storing sweet potato (Ipomoea batatas L. Lam) shoot cutting planting materials for increased tuber yield. Trop. Sci. 31:1-7.

Pardales, J.R., D.M. Banoc, A. Yamauchi, M. Iijima, and C.B. Esquibel. 2000. The effect of fluctuations of soil moisture on root development during the establishment phase of sweetpotato. Plant Prod. Sci. 3:134-139.

Pardales, J.R. and A. Yamauchi. 2003. Regulation of root development in sweetpotato and cassava by soil moisture during their establishment period. Plant Soil 255:201-208.

Ravindran, C.S. and C.R. Mohankumar. 1989. Effect of storage life of vines with and without leaves on the establishment and root yield of sweet potato. J. Root Crops 15:145-146.

Sand Hill Preservation Center. 2017. Sweet potato. 1 Nov. 2017. <http:// www.sandhillpreservation.com/2017_ pdf/Sweetpotato2017.pdf>.
Stoddard, C.S., R.M. Davis, and M. Cantwell. 2013. Sweetpotato production in California. Univ. California, Agr. Natural Resources, Veg. Production Ser. Bul. 7237.

Thompson, W.B., J.R. Schultheis, S. Chaudhari, D.W. Monks, K.M. Jennings, and G.L. Grabow. 2017. 'Covington' sweetpotato plant survival and yield response to preplant irrigation, planting depth, and transplant size. HortTechnology 27:824830 .

Togari, Y. 1950. A study of tuberous root formation in sweet potato. Bul. Natl. Agr. Expt. Sta. Tokyo 68:1-96.

U.S. Department of Agriculture. 2005. United States standards for grades of sweetpotatoes. U.S. Dept. Agr., Washington, DC.

U.S. Department of Agriculture. 2016. Crop production 2015 summary. U.S. Dept. Agr., Washington, DC.

Villordon, A., D.R. LaBonte, and N. Firon. 2009. Development of a simple thermal time method for describing the onset of morpho-anatomical features related to sweetpotato storage root formation. Scientia Hort. 121:374-377.

Villordon, A., D.R. LaBonte, J. Solis, and N. Firon. 2012. Characterization of lateral root development at the onset of storage root initiation in Beauregard sweetpotato adventitious roots. HortScience 47:961968.

Wilson, L.A. 1970. The process of tuberization in sweet potato (Ipomoea batatas (L.) Lam.). Proc. Intl. Symp. Trop. Root Crops 2:24-26. 